\title{
PELATIHAN TATA KELOLA ORGANISASI PUBLIK BAGI PENERIMA HIBAH PEMBANGUNAN MASJID
}

\author{
Frank Aligarh ${ }^{1)}$ \\ 1)Program Studi Akuntansi Syariah, Fakultas Ekonomi dan Bisnis Islam, Universitas Islam Negeri (UIN) Raden MasSaid \\ Surakarta, Surakarta, Jawa Tengah, Indonesia \\ Corresponding author: Frank Aligarh \\ E-mail: frank.aligarh@iain-surakarta.ac.id
}

Diterima 15 Juli 2021, Direvisi 03 Agustus 2021, Disetujui 03 Agustus 2021

\begin{abstract}
ABSTRAK
Jumlah masjid di Indonesia yang semakin meningkat harusnya diikuti dengan tata kelola yang semakin baik. Berdasarkan observasi pendahuluan diketahui bahwa masih banyak terdapat pengelolaan masjid yang belum memilki tata kelola organisasi publik yang baik. Tujuan Kegiatan pengabdian masyarakat ini adalah untuk memberikan alternatif informasi tentang tata kelola organisasi publik yang baik dan mendampingi pengelola masjid dalam menyusun laporan keuangan masjid yang baik. Peserta kegiatan pengabdian masyarakat ini adalah pengelola masjid penerima hibah pembangunan masjid sejumlah 50 orang. Metode kegiatan ini terdiri dari 3 Tahapan yaitu (1) Tahapan Persiapan, (2) Tahapan Implementasi, (3) Tahapan Monitoring dan Evaluasi. Setelah kegiatan pengabdian masyarakat dilakukan pengelola masjid telah memiliki pengetahuan mengenai tata cara pembuatan struktur organisasi masjid, tugas dan fungsi pengelola masjid program kerja masjid. Lebih lanjut, pengelola masjid juga sudah memiliki ketrampilan dalam mengoperasikan program akuntansi berbasis excel yang dapat digunakan untuk pembuatan laporan keuangan.
\end{abstract}

Kata kunci: pengabdian masyarakat; tata kelola; akuntabilitas; masjid.

\begin{abstract}
The increasing number of mosques in Indonesia should be followed by better governance. Based on preliminary observations, it is known that there are still many mosque managements that do not have good public organizational governance. The purpose of this community service activity is to provide alternative information about good public organizational governance and assist mosque managers in preparing good mosque financial reports. Participants in this community service activity are mosque managers who receive 50 mosque construction grants. This activity method consists of 3 stages, namely (1) Preparation Stage, (2) Implementation Stage, (3) Monitoring and Evaluation Stage. After the community service activities are carried out, the mosque manager has knowledge about the procedures for making the mosque's organizational structure, the duties and functions of the mosque manager, the mosque work program. Furthermore, mosque managers also have skills in operating excel-based accounting programs that can be used for financial reporting
\end{abstract}

Keywords: community service; governance; accountability; mosque.

\section{PENDAHULUAN}

Indonesia merupakan Negara dengan mayoritas penduduk muslim terbesar di dunia. Dengan jumlah penduduk muslim yang besar tentunya diikuti dengan jumlah tempat ibadah atau masjid yang besar pula. Berdasarkan data Sistem Informasi Masjid Kementerian Agama di ketahui bahwa jumlah masjid yang terdaftar sejumlah 279.241 dan Mushalla sejumlah 329.105 (simas.kemenag.go.id).

Masjid beserta tata kelolanya bisa dikategorikan sebagai organisasi publik karena tidak hanya berfungsi sebagai pelayanan publik dalam hal ini ibadah tetapi juga menghimpun dana berupa zakat, infaq, dan shodaqoh serta menyalurkan dana tersebut dalam rangka menyejahterakan kehidupan masyarakat dan dalam rangka memakmurkan masjid.

Kompleksitas pengelolaan masjid yang terus meningkat tentunya juga harus diikuti dengan peningkatan tata kelola yang baik. Salah satu wujud tata kelola yang baik adalah terciptannya akuntabilitas publik.

Akuntabilitas publik merupakan bentuk pertanggungjawaban baik dari aspek keuangan maupun kinerja bagi setiap organisasi publik dalam hal ini masjid kepada para stakeholdernya yaitu muzakki, jama'ah masjid, masyarakat luas, dan pemerintah. Lebih lanjut Siskawati et al., (2016); Sofyani, (2018) 
menjelaskan dengan adanya akuntabilitas publik yang baik diharapkan kepercayaan masyarakat akan meningkat dan mengurangi konflik sesama pengguna masjid.

Berdasarkan observasi dan wawancara pendahuluan kepada anggota Ikatan Masjid Ahlu Sunnah (IMAS) atau organisasi pengelola masjid penerima hibah masjid Kabupaten Klaten yang beranggotakan lebih dari 300 masjid diketahui bahwa masih banyak terdapat pengelola masjid yang belum melaksanakan tata kelola dengan baik.

Beberapa permasalahan yang dihadapi pengelola masjid diantarannya adalah (1) belum adanya struktur organisasi yang jelas, (2) belum adanya program kerja tahunan yang baku, (3) belum terdapat pembukuan dan pencatatan keuangan yang baik, (4) belum terdapat perencanaan pengeluaran keuangan baik operasional maupun non operasional yang jelas, (5) belum terdapat sistem pelaporan keuangan tahunan yang baku.

Permasalahan diatas juga ditemukan oleh beberapa penelitian terdahulu diantaranya adalah penelitian Yuliarti, (2019) yang menjelaskan bahwa masih banyak terdapat masjid yang belum memiliki sistem tata kelola yang baik. Hal tersebut juga sejalan dengan Firdaus \& Yulianto, (2018) yang menyebutkan bahwa masjid biasanya hanya menggunakan pembukuan manual yang tentunya menurunkan kredibilitas dan kepercayaan publik dalam kaitanya dengan akuntabilitas.

Berdasarkan observasi pendahuluan dan hasil penelitian sebelumnya maka dilakukan kegiatan pelatihan sekaligus pendampingan tata kelola masjid bagi penerima hibah pembangunan masjid di Kabupaten Klaten. Kegiatan tersebut merupakan bentuk pengabdian kepada masyarakat yang dilakukan oleh dosen dengan tujuan untuk memberikan alternatif informasi tentang tata kelola organisasi publik yang baik dan mendampingi pengelola masjid dalam menyusun laporan keuangan masjid yang baik.

\section{METODE}

Kegiatan pengabdian masyarakat yang berupa pelatihan tata kelola organisasi publik bagi penerima hibah pembangunan masjid dilaksanakan pada 25 Juli 2020 bertempat di Gedung Dakwah Muhammadiyah Pimpinan Cabang Muhammadiyah (PCM) Kecamatan Wedi Kabupaten Klaten Provinsi Jawa Tengah. Kegiatan tersebut diikuti oleh 50 peserta dari berbagai kecamatan di Kabupaten Klaten diantarannya dari Kecamatan Wedi, Bayat, Cawas, Jatinom, Jogonalan, Klaten Utara, Klaten Selatan, Klaten Tengah dan Ngawen. Dalam pelaksanaanya kegiatan dimulai dengan tiga tahapan diantarannya adalah (1) Tahapan Persiapan, (2) Tahapan Implementasi, (3) Tahapan Monitoring dan Evaluasi. Tahapan persiapan terdiri observasi dan wawancara dengan pengelola masjid dan penasehat IMAS serta analisa kebutuhan.

Tahapan implementasi terdiri dari sosialisasi kegiatan dan penyampaian materi mengenai tata kelola masjid yang berisi mengenai struktur organisasi, job deskripsi dan program kegiatan serta pendampingan pembukuan keuangan berbasis excel. Tahapan monitoring dan evaluasi berisi tentang pengawasan kegiatan dan pengelolaan masjid yang dilakukan setiap pengelola masjid setelah menerima pelatihan.

\section{HASIL DAN PEMBAHASAN}

Kegiatan pengabdian masayarakat terdiri dari tiga tahapan yaitu: (1) Tahapan Persiapan, (2) Tahapan Implementasi, (3) Tahapan Monitoring dan Evaluasi. Tahapan persiapan dimulai dari observasi dan wawancara terhadap pengelola masjid yang tergabung dengan Ikatan Masjid Ahlu Sunnah (IMAS) dan pengurus IMAS.

Dalam proses observasi diketahui sebagian besar pengelola masjid yang menerima hibah pembangunan masjid telah melaksanakan kegiatan peribadahan kurang lebih 2-5 Tahun sejak masjid dibangun atau direnovasi dari masjid sebelumnya. Dari observasi juga diketahui bahwa sebagian pengelola masjid belum memiliki struktur organisasi masjid baku, sementara itu sebagian pengelola masjid baru membentuk organisasi tetapi belum memiliki job deksripsi yang jelas. Selain hal tersebut terdapat beberapa pengelola masjid yang belum memiliki program kerja masjid yang terukur sehingga mengakibatkan pengelola masjid tidak berani mengambil resiko mengeluarkan uang infaq selain kebersihan dan perawatan masjid. Lebih lanjut, dalam proses pembukuan masih menggunakan cara yang tradisional sehingga dalam pelaporannya belum bisa memberikan informasi yang komprehensif.

Hasil observasi dengan pengurus IMAS atau penasehat IMAS memberikan gambaran bahwa selama ini pendampingan hanya dilakukan pada level kegiatan rutin masjid seperti ibadah sholat, kegiatan buka puasa dan pengelolaan infaq. Lebih lanjut, dalam inovasi kegiatan masih terbatas dan pengelolaan keuangan yang profesional belum dilakukan karena terkendala sumber daya manusia.

Setelah melakukan observasi kemudian tahapan berikutnya melakukan pemetaan analisa kebutuhan. Dari hasil pemetaan, kebutuhan yang harus segera 
dilakukan adalah pelatihan tata kelola masjid yang berisi mengenai struktur organisasi, job deskripsi dan program kegiatan. Kemudian kebutuhan berikutnya adalah pendampingan pembukuan keuangan berbasis excel.

Tahapan berikutnya adalah implementasi, sebelum pelaksanaan kegiatan dilakukan penulis telah memberikan sosialisasi secara daring dan memberikan formulir secara daring untuk keikutsertaan dalam kegiatan pelatihan tersebut. Jumlah peserta yang mengikuti kegiatan adalah 50 orang.

Kegiatan dimulai dengan pembukaan oleh koordinator IMAS dikuti oleh perwakilan dari tim dosen yang dapat dilihat pada gambar 1. Selanjutnya adalah penyampaian materi sesi 1 mengenai tata kelola masjid. Dalam materi tersebut peserta diberikan contoh mengenai struktur organisasi, program kegiatan masjid, dan uraian tugas dan fungsi masing masing pengelola masjid. Salah satu contoh tata kelola masjid yang baik adalah Masjid Jogokariyan Yogyakarta.

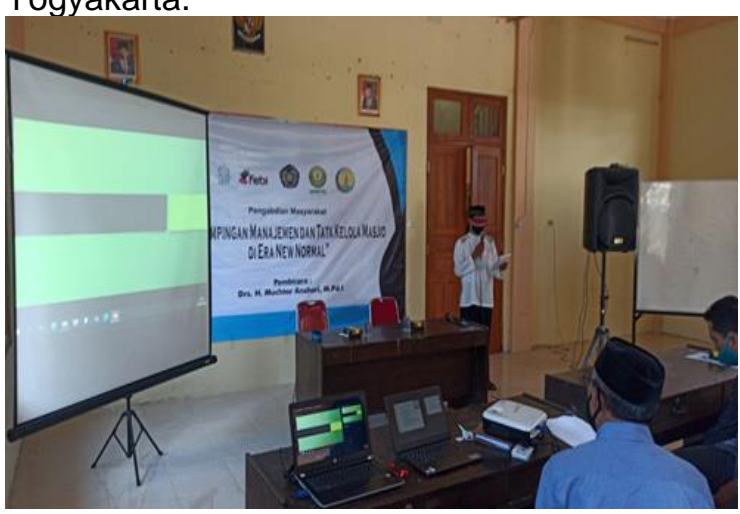

Gambar 1. Pembukaan Kegiatan Pelatihan

Fenomena pengelolaan masjid yang baik dari Masjid Jogokariyan memang sudah banyak diteliti. Pramesvari, (2019) menyebutkan bahwa walaupun pengelolaan keuangan belum secara penuh mengadopsi PSAK 45 tentang organisasi nirlaba dan PSAK 109 akuntansi, zakat, infaq, shodaqoh akan tetapi secara prinsip akuntabilitas dan transparansi bisa dijadikan rujukan pengelolaan masjid yang baik di Indonesia. Hal tersebut ditandai dengan penyampaian informasi berkaitan pengeluaran dan penerimaan yang secara rutin disampaikan dan informasi kegiatan yang mudah diakses bagi setiap anggota masyarakat.

Pada gambar 2, selain penyampaian materi, dalam sesi tersebut juga dilakukan praktik penyusunan struktur organisasi sekaligus menyusun program-program kerja yang dianggap mampu dan relevan sesuai dengan kondisi masing-masing masjid.

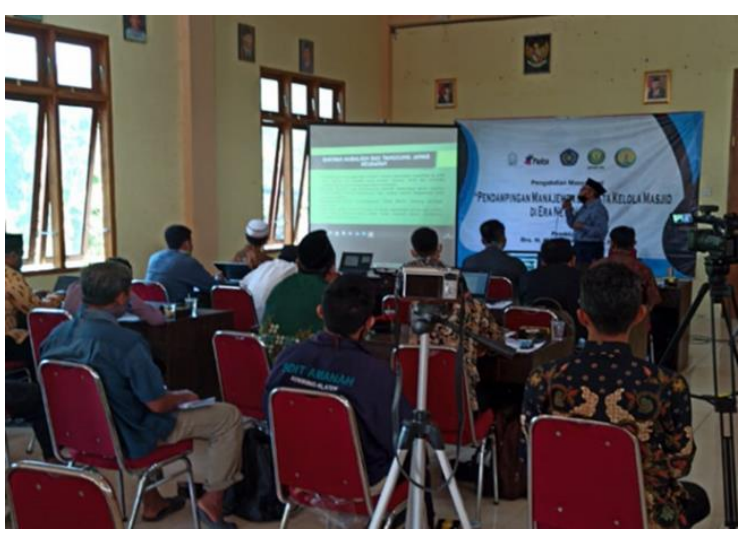

Gambar 2. Penyampaian Materi Tata Kelola

Pada sesi kedua peserta kegiatan pengabdian masyarakat tersebut mendapatkan materi akuntansi berbasis excel. Dalam gambar 3 peserta kegiatan pegabdian masyarakat menerima materi sekaligus praktik mengenai aplikasi excel yang terintegrasi dari mulai pencatatan transaksi sampai dengan luaran yang nantinya dijadikan dasar sebagai laporan keuangan yang dipublikasikan oleh pengelola masjid.

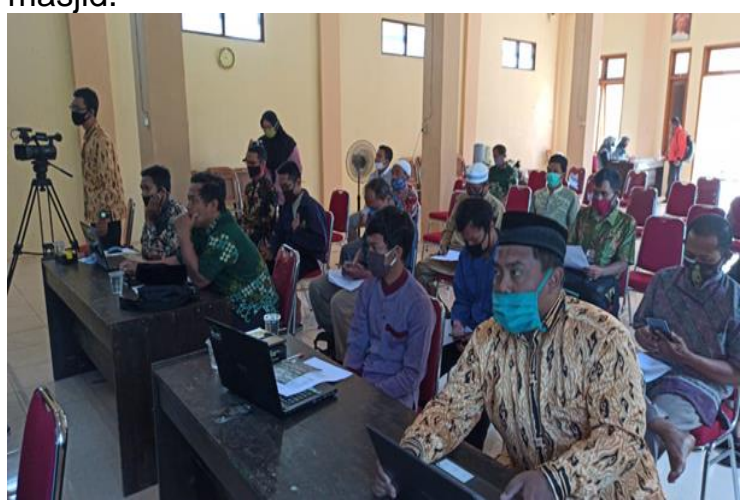

Gambar 3. Praktik Akuntansi Berbasis Excel

Materi yang dibahas dalam sesi tersebut adalah jurnal transaksi, buku besar, neraca dan penyajian laporan penerimaan dan pengeluaran. Peserta kegiatan pengabdian masyarakat terlebih dahulu diberikan file yang berisi aplikasi excel. Selanjutnya peserta diberi latihan soal berkaitan dengan transaksi yang mungkin terjadi dalam kegiatan di masjid.

Peserta pengabdian masyarakat mengerjakan secara manual terlebih dahulu jurnal transaksi dibantu dengan instruktur dari tim pengabdian masyarakat. Selanjutnya setelah memahami logika jurnal transaksi peserta praktik menggunakan aplikasi berbasis excel. Peserta memasukkan satu persatu transaksi ke dalam excel. Dalam aplikasi tersebut juga sudah tersedia akun-akun yang disesuiakan dengan kebutuhan pengelolaan masjid.

Setelah proses selesai tahap awal peserta diberikan materi mengenai buku besar 
dan neraca. Dalam materi ini jika peserta dalam mengerjakan manual harus memindahkan dari jurnal transaksi menuju buku besar maka dalam aplikasi ini setelah mengerjakan jurnal transaksi maka secara otomatis data akan masuk di buku besar dan neraca.

Pada sesi terakhir peserta diberikan materi mengenai menyusun laporan keuangan. Luaran dari aplikasi tersebut bbisa digunakan bagi pengelola masjid untuk melaporkan mengenai penerimaan dan pengeluaran masjid serta untuk melihat total aset yang dimiliki masjid sampai tahun berakhirnya tutup buku.

Setelah penyampaian sesi 2 berakhir maka tahapan berikutnya adalah monitoring dan evaluasi. Dalam sesi ini tim pengabdian masyarakat memberikan beberapa informasi sekaligus Tanya jawab seputar kondisi terkini dari setiap masjid. Sesi tersebut juga disampaikan bahwa penyampaian informasi keuangan yang baik kepada jamaah masjid dan masyarakat di sekitar masjid akan mengurangi konflik yang disebabkan karena asimetri informasi anatara pengelola masjid dan stakeholdernya dalam hal ini masyarakat dan pemerintah.

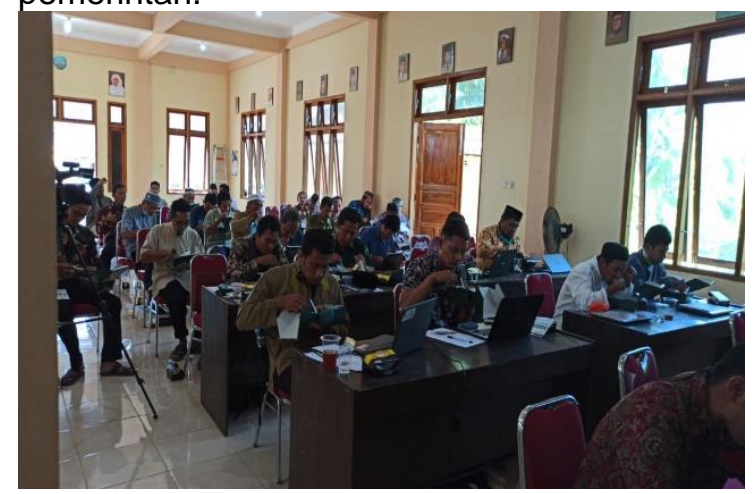

Gambar 4. Evaluasi dan Tanya Jawab

Kegiatan monitoring dan evaluasi tidak hanya selesai dalam hari tersebut. Lebih lanjut, tim pengabdian masyarakat akan melakukan monitoring dan evaluasi secara daring kepada anggota IMAS kaitannya dengan tata kelola organisasi masjid dan pengembangan pembukuan keuangan yang dilakukan oleh masing-masing masjid. Harapannya walaupun mungkin belum sesuai dengan PSAK 45 tentang organisasi nirlaba dan PSAK 109 (Akuntansi, Zakat, Infaq, Shodaqoh) akan tetapi sudah memiliki visi menuju tata kelola yang transparan dan akuntabel (Sriyono et al., 2019).

Kegiatan selesai dengan pembagian hadiah berupa buku dari pengurus IMAS. Kegiatan tersebut tidak hanya mendapatkan dukungan dari pengelola masjid tetapi juga dari masyarakat luas pada umumnya.

\section{SIMPULAN DAN SARAN}

Kegiatan pengabdian masyarakat ini memiliki kontribusi tidak hanya pada aspek transfer knowledge, tetapi juga ketrampilan bagi setiap pengelola dalam menggunakan aplikasi excel yang berisi program laporan keuangan. Program tersebut disusun secara sederhana sehingga memberikan kemudahan dan kebermanfaatan bagi setiap pengelola masjid. Kedepan para pengelola masjid dapat secara profesional dalam pengelolaan masjid terutama dalam pengelolaan keuangan sehingga dalam proses penentuan program kerja pengelola masjid tidak hanya berfokus pada aspek pembangunan masjid tetapi juga pembangunan sumber daya manusia di sekitar masjid.

Tantangan mengenai akuntabilitas publik memang tidak mudah, hal tersebut karena untuk pelaporan memang tidak ada aturan formal yang mengharuskan untuk membuat laporan tersebut. Kebanyakan praktik pelaporan yang dilakukan didasari karena faktor religiusitas dan rasa saling percaya oleh masing-masing pengelola dan pengurus masjid. Pemberdayaan sumber daya manusia yang terstruktur dan sistematis perlu dilakukan karena kompleksitas pengelolaan masjd semakin meningkat.

Kegiatan pengabdian masyarakat yang berorientasi pada tata kelola masjid kedepan sebaiknya difokuskan kepada aspek penyajian laporan keuangan yang sesuai PSAK 45 dan PSAK 109. Hal tersebutmerupakan kelanjutan kegiatan setelah dilakukannya pelatihan pembukuan keuangan secara sederhana.

\section{UCAPAN TERIMAKASIH}

Penulis mengucapkan terima kasih kepada Fakultas Ekonomi dan Bisnis Islam (FEBI) Universitas Islam Negeri (UIN) Raden Mas Said Surakarta yang telah memberikan hibah pendanaan untuk kegiatan pengabdian masyarakat. Penulis juga mengucapkan terima kasih kepada Mitra kegiatan yaitu pengelola masjid penerima hibah yang tergabung dalam organisasi IMAS.

\section{DAFTAR RUJUKAN}

Firdaus, D. W., \& Yulianto, H. D. (2018). Perancangan sistem informasi akuntansi entitas nirlaba dalam penyajian laporan keuangan berbasis akuntabilitas masjid. Jurnal Riset Akuntansi Dan Keuangan, 6(1), 25-44.

Pramesvari, L. N. (2019). Fenomena Pengelolaan dan Pelaporan Masjid Jogokariyan Yogyakarta Pada Aspek Mental, Fisik Dan Spiritual. Jurnal Ekonomi, Bisnis, Dan Akuntansi, 21(3). 
Siskawati, E., Ferdawati, F., \& Surya, F. (2016).

Pemaknaan Akuntabilitas Masjid:

Bagaimana Masjid Dan Masyarakat Saling Memakmurkan? Jurnal Akuntansi Multiparadigma, 7(1), 70-80.

Sofyani, H. (2018). Pendampingan manajemen dan tata kelola masjid serta lembaga amil zakat infak dan sodaqoh. Jurnal Pengabdian UntukMu NegeRI, 2(2), 6067.

Sriyono, S., Sari, D. K., Febriansah, R. E., \& Prapanca, D. (2019). Pendampingan tata kelola dan manajemen pada kegiatan abdimas masjid. Jurnal Terapan Abdimas, 4(2), 198-202.

Yuliarti, N. C. (2019). Akuntansi Masjid Sebagai Solusi Transparansi Dan Akuntabilitas Publik. Jurnal Penelitian IPTEKS, 4(1), 13-21. 